\title{
EVALUASI PEMAJAKAN ATAS NILAI TAMBAH DALAM BIAYA ANGKUTAN LAUT DAN UDARA (FREIGHT) KARGO PADA PERUSAHAAN FREIGHT FORWARDING DI INDONESIA
}

\author{
Chairil Anwar Pohan dan Pebriana Arimbhi \\ Institut Ilmu Sosial dan Manajemen Stiami \\ anwar.phn@gmail.com dan pebrianasusanto@yahoo.co.id
}

\begin{abstract}
Pemberlakuan penerapan dasar pengenaan pajak berupa Nilai Lain untuk Freight Charges telah menjadi suatu "terobosan" yang smart terhadap prinsip-prinsip dasar dan karakteristik perpajakan yang terkandung dalam PPN dan mekanisme PPN, dan kebijakan ini dianggap "berhasil" mengangkat suatu complicated issue yang terkandung dalam aspek fiskal (theoritical concept untuk membidik selisih freight) padahal sebenarnya tidak ada suatu urgensi atau complicated issue dari aspek fiskal yang mengharuskan untuk me "nilai lain" kan freight charges tersebut untuk perhitungan/ pengenaan PPN atas freight charges di dalam transaksi penyerahan Jasa Freight Forwading. Meskipun fiskus membuat "terobosan" pemajakan atas freight yang selama ini dianggap "untaxable", namun di sisi lain disayangkan konsep pemajakan yang berbasiskan Peraturan Menkeu No. 38/PMK.011/2013 tentang perubahan atas Peraturan Menkeu No. 75/PMK.03/2010 tentang Nilai Lain tersebut bisa mendatangkan kerugian/ kekurangan bagi pemasukan negara, karena mekanisme PPN terganggu akibat secara theoritical concept dari tax base-nya tidak terbidik secara efektif. Dari sudut pandang revenue productivity principle, konsep tersebut menimbulkan permasalahan baru yang sebenarnya tidak perlu terjadi karena pada dasarnya timbulnya realisasi transaksi selisih freight yang dapat "dijaring" dari pembukuan komersial yang diselenggarakan berbasiskan Standard Akuntansi Keuangan yang berlaku sudah merupakan suatu indikasi terciptanya suatu nilai tambah yang menjadi objek pengenaan PPN. Pemberlakuan penerapan dasar pengenaan pajak berupa Nilai Lain untuk Freight Charges telah "merusak" nilai prinsip-prinsip dasar dan karakteristik perpajakan yang terkandung dalam PPN dan mekanisme PPN dengan cara me "nilai lain" kan freight charges tersebut untuk perhitungan/ pengenaan PPN atas freight charges di dalam transaksi penyerahan Jasa Pengurusan Transportasi atau Freight Forwading (JPT/FF).
\end{abstract}

Kata Kunci : Freight, Selisih Freight, PPN, Penerimaan Negara

\begin{abstract}
Enactment of the application of the tax base in the form of Other Values for Freight Charges has become a smart breakthrough"of the basic principles and tax characteristics contained in the VAT and VAT mechanism, and this policy is considered Successful'raised a complicated issue contained in the aspect fiscal (theoretical concept to aiming the difference in freight) when in fact there is no urgency or complicated issue from the fiscal aspect that requires to "other value" the freight charges for the calculation/imposition of VAT on freight charges in the delivery transaction of Freight Forwarding Services. Although taxpayers make a breakthrough"of taxation on freight that has been considered Untaxable"beforehand, but on the other side, it is unfortunately the concept of taxation based on Regulation Finance Minister no. 38 / PMK.011 / 2013 on amendment to Regulation of the Minister of Finance no. 75 / PMK.03 / 2010 concerning other Values may cause losses for state revenues, because the VAT mechanism is disrupted due to theoretical concept of the tax base has not effectively being aiming. From the point of view of revenue productivity principle, the concept raises a new problem that really does not need to happen because basically the realization of the transactions of freight differences that can be captured"from commercial bookkeeping held based on the applicable Financial Accounting Standard is an indication of the creation of an added value that become the object of VAT imposition. The application of the tax base in the form of Other Values for Freight Charges has damaged'the value of the basic principles and tax characteristics contained in the VAT and VAT mechanism by means of to bther value"such freight charges for VAT calculation/imposition of VAT on freight charges in delivery transactions of Freight Forwarding Services (JPT / FF).
\end{abstract}

Keywords: Freight, Freight Difference, VAT, State Revenue 


\section{PENDAHULUAN}

Suatu solusi oleh fiskus sebagai "terobosan" pemajakan atas freight yang selama ini dianggap "untaxable", namun di sisi lain disayangkan konsep pemajakan yang berbasiskan Peraturan Menkeu No. 38/PMK.011/2013 tentang perubahan atas Peraturan Menkeu No. 75/PMK.03/2010 tentang Nilai Lain tersebut bisa mendatangkan kerugian/kekurangan bagi pemasukan negara, karena mekanisme PPN terganggu akibat secara theoritical concept dari tax base-nya tidak terbidik secara efektif. Konsep yang ditawarkan sudah baik yakni untuk "menangkap adanya potensi PPN yang terkandung dalam freight sebagai pendapatan negara", namun dari sudut pandang revenue productivity principle, konsep tersebut menimbulkan permasalahan baru yang sebenarnya tidak perlu terjadi karena pada dasarnya timbulnya realisasi transaksi selisih freight yang dapat "dijaring" dari pembukuan komersial yang diselenggarakan berbasiskan Standard Akuntansi Keuangan yang berlaku sudah merupakan suatu indikasi terciptanya suatu nilai tambah yang menjadi objek pengenaan PPN.

Peraturan di Bidang Transportasi yang terkait dengan freight charges di dalam transaksi penyerahan Jasa Pengurusan Transportasi atau Freight Forwading (JPT/FF) adalah : 1). Undang-Undang No. 17 Tahun 2008 tentang Pelayaran, dan Peraturan Pemerintah Nomor 20 Tahun 2010 tentang Angkutan di Perairan.

2). Pemerintah mengeluarkan Peraturan Menteri Keuangan No.75/PMK.03/2010 sebagaimana direvisi dengan PMK No. 38/PMK.011/2013), dimana selanjutnya dalam PMK No. 38/PMK.011/2013 tersebut ditambahkan satu item nilai lain yakni "untuk penyerahan jasa pengurusan transportasi (freight forwarding) yang didalam tagihan jasa pengurusan transportasi tersebut terdapat biaya transportasi (freight charges) adalah $10 \%$ (sepuluh persen) dari jumlah yang ditagih atau seharusnya ditagih". Jumlah yang ditagih atau seharusnya ditagih adalah hasil dari keseluruhan proses menagih atas nilai penyerahan JPT/FF oleh perusahaan JPT/FF kepada pengguna JPT/FF, yang besarnya sama dengan nilai penyerahan JPT/FF itu sendiri sebagai satu kesatuan tanpa membedakan apakah nilai penyerahan JPT/FF tersebut ditagih dengan satu atau beberapa dokumen tagihan. 3) Sementara itu, Pajak Masukan yang berhubungan dengan penyerahan jasa pengurusan transportasi (freight forwarding) yang di dalam tagihan jasa pengurusan transportasi tersebut terdapat biaya transportasi (freight charges) yang dilakukan oleh perusahaan JPT/FF, tidak dapat dikreditkan. 4) Walaupun penyerahan JPT/FF dapat terdiri dari satu atau beberapa kegiatan, satu atau beberapa kegiatan yang diserahkan tersebut tetap merupakan satu kesatuan, yaitu penyerahan JPT/FF, sehingga kewajiban Pengusaha Kena Pajak untuk membuat Faktur Pajak atas setiap penyerahan Jasa Kena Pajak wajib dilakukan.

Pemberlakuan penerapan dasar pengenaan pajak berupa Nilai Lain untuk Freight Charges telah "merusak" nilai prinsip-prinsip dasar dan karakteristik perpajakan yang terkandung dalam PPN dan mekanisme PPN dengan cara me "nilai lain" kan freight charges tersebut untuk perhitungan/ pengenaan PPN atas freight charges di dalam transaksi penyerahan Jasa Pengurusan Transportasi atau Freight Forwading (JPT/FF). Dalam Peraturan Menkeu No. 38/PMK.011/2013 ditambahkan satu item nilai lain yakni "untuk penyerahan jasa pengurusan transportasi (freight forwarding) yang didalam tagihan jasa pengurusan transportasi tersebut terdapat freight charges adalah 10\% dari jumlah yang ditagih atau seharusnya ditagih". Pemberlakuan penerapan dasar pengenaan pajak berupa Nilai Lain untuk Freight Charges telah menjadi suatu "terobosan" yang smart terhadap prinsip-prinsip dasar dan karakteristik perpajakan yang terkandung dalam PPN dan mekanisme PPN, dan kebijakan ini "berhasil" mengangkat suatu complicated issue yang terkandung dalam aspek fiskal (theoritical concept untuk membidik selisih freight) padahal sebenarnya tidak ada suatu urgensi atau complicated issue dari aspek fiskal yang mengharuskan untuk me "nilai lain" kan freight charges tersebut 
untuk perhitungan/ pengenaan PPN atas freight charges di dalam transaksi penyerahan Jasa Freight Forwading.Antara ketentuan pemajakan lama dengan pemajakan baru pengenaan PPN terhadap Freight, dapat dikomentari bahwa ketentuan pemajakan baru atas freight tersebut tanpa disadari telah melanggar Pasal 4A UU PPN No. 42/2009 ayat 3 huruf $\mathrm{j}$ yang menyebutkan jenis jasa yang tidak dikenai PPN adalah jasa tertentu dalam kelompok jasa "jasa angkutan umum di darat dan di air serta jasa angkutan udara dalam negeri yang menjadi bagian yang tidak terpisahkan dan jasa angkutan udara luar negeri”, karena dasar perhitungan PPN adalah $10 \% \times 10 \% \times$ nilai jual freight atau $1 \%$ x nilai jual freight. Berbeda halnya bila sistem pemajakannya dirobah dengan dasar perhitungan menjadi $10 \%$ x selisih freight, ini tentu saja tidak melanggar regulasi pajak yang ada serta tidak pula melanggar kaidah destinasi dan kaidah Netralitas (Neutrality principle).

\section{METODE PENELITIAN}

Metode penelitian yang digunakan dalam penelitian ini adalah metode deskriptif. Sedangkan pendekatan penelitian yang digunakan adalah pendekatan kualitatif. Pada metode penelitian kualitatif ini, metode penelitian yang digunakan untuk meneliti pada kondisi obyek yang alamiah, dimana peneliti adalah sebagai instrumen kunci, teknik pengumpulan data dilakukan secara triangulasi (gabungan), analisa data bersifat induktif, dan hasil penelitian kualitatif lebih menekankan makna dari pada generalisasi. Dimensi penelitian bersifat case study, dalam arti melakukan kajian terhadap satu realitas sosial. Dalam penelitian ini, peneliti menerapkan studi kasus dalam arti studi mendalam yang dikaji dari berbagai aspek yang sekaligus sebagai strategi untuk memperoleh data yang bersangkutan. Pendekatan kualitatif menerapkan paradigma naturalistic, dimana penelitiannya dilakukan pada kondisi alamiah (natural setting). Data kualitatif berupa hasil wawancara mendalam, observasi, studi kepustakaan dan dokumentasi, namun juga dimungkinkan menggunakan data kuantitatif sebagai pelengkap informasi pada setiap pertanyaan analisis penelitian.Teknik Pengumpulan Data menggunakan: 1.Studi Kepustakaan: data yang dikumpulkan dari beberapa perusahaanperusahaan freight forwarding, sebanyak 4(empat) perusahaan, yakni : PT. S. International Indonesia, PT. TBS, PT MAS dan PT MKST. 2. In-depth, opened ended interviews: untuk memperkuat hasil analisa dan pembahasan, penulis juga melakukan wawancara yang mendalam dengan para informan (eksekutif, konsultan pajak, Asosiasi Freight Forwarder serta Mantan Kepala Kantor Pelayanan Pajak).

\section{HASIL PENELITIAN DAN PEMBAHASAN}

- Kurangnya penerimaan Negara dari pemungutan PPN yang berasal dari pemajakan atas nilai tambah dalam biaya freight kargo laut dan udara pada Perusahaan Jasa Pengurusan Transportasi atau Jasa Freight Forwarding Nasional paska dikeluarkannya peraturan Menkeu No.75/PMK.03/2010 tentang Nilai Lain" sebagai dasar pengenaan pajak, akibat secara theoritical concept dari tax basenya tidak terbidik secara efektif. Ini dapat dilihat di banyak Perusahaan Jasa Pengurusan Transportasi seperti di PT.TBS, PT. MAS dan PT. MKST Jakarta bahwa ternyata penerapan pemajakan PPN atas Nilai Tambah dalam biaya Jasa Freight Forwarding belum sepenuhnya sesuai dengan teori/kaidah-kaidah atau prinsip-prinsip PPN. Dari paparan contoh beberapa Invoice dan faktur pajak yang diterbitkan oleh PT. MAS dan PT. MKST, ternyata masih terdapat kekeliruan dari perusahaan Freight Forwarding tersebut dalam penerapan PPN 1\% (SE No. $33 / \mathrm{PJ} / 2013$ ), dimana seharusnya yang boleh ditagihkan PPN 1\% yakni bila dalam Invoice tersebut termasuk unsur Freight. Bila ada unsur Freight di dalam Invoice/Faktur Pajak tersebut, maka faktur pajak yang ditagihkan kepada shipper adalah $1 \%$ dari nilai Invoice, bila tidak, maka maka faktur pajak yang ditagihkan 
kepada shipper adalah $10 \%$ dari nilai Invoice. Tentu saja praktik pemajakan PPN semacam [yang hanya menagih PPN $1 \%$ (yang seharusnya 10\%) dari nilai Invoice padahal tidak ada unsur Freight di dalam Invoice/Faktur Pajak tersebut], hal itu akan menimbulkan kerugian/kurangnya penerimaan bagi negara yang potensinya sangat besar jumlahnya.

Dalam menjawab konsep apa yang lebih tepat sebagai alternatif pengenaan PPN di dalam transaksi penyerahan Jasa Pengurusan Transportasi atau Freight Forwarding atas freight charges tanpa melanggar kaidah-kaidah atau prinsipprinsip PPN pada setiap shipment ekspor kargo paska berlakunya Peraturan Menkeu No. 38/PMK.011/2013 tersebut, hal ini dapat dijelaskan berikut ini.

Sebenarnya selisih freight yang merupakan tambahan biaya yang dibebankan oleh perusahaan jasa International Freight Forwarding kepada pelanggannya merupakan Jasa Pengurusan Transportasi dan tidak termasuk dalam jasa freight yang tidak dikenakan PPN.Oleh sebab itu selisih freight tersebut memiliki potensi sebagai objek PPN. Pengenaan PPN atas selisih freight tadi sangat cocok dan aplikatif bila menerapkan metode Subtraction atau Subtractive Direct Method sebagai konsep alternatif selain harus me "nilai lain" kan freight charges dalam pengenaan PPN atas freight charges di dalam transaksi penyerahan Jasa Freight Forwarding tanpa melanggar kaidah/prinsip PPN. Pada dasarnya timbulnya realisasi transaksi selisih freight dapat "dijaring" dari pembukuan komersial (atas transaksi pembelian dan penjualan jasa freight) yang diselenggarakan berbasiskan Standard Akuntansi Keuangan yang berlaku, ini sudah merupakan suatu indikasi terciptanya suatu nilai tambah yang menjadi objek pengenaan PPN. Jadi Pengusaha Kena Pajak Freight Forwarder cukup membuat perhitungan berapa Selisih PPN (dari Nilai freight yang dijual ke shipper/eksportir/pengirim kargo dikurangi dengan nilai freight yang dibeli dari perusahaan pelayaran/penerbangan).

\section{KESIMPULAN DAN SARAN}

- Regulasi pemajakan yang berbasiskan Peraturan Menkeu No. 38/PMK.011/2013 tentang "Nilai Lain" sebagai dasar pengenaan pajak bisa mendatangkan kerugian/kekurangan bagi pemasukan negara, karena mekanisme PPN terganggu akibat secara theoritical consept dari tax base-nya tidak terbidik secara efektif.

- Pada hakekatnya sistem PPN memiliki konsep alternatif pengenaan PPN dalam transaksi penyerahan Jasa Freight Forwading atas freight charges tanpa melanggar kaidah-kaidah atau prinsipprinsip PPN yaitu dengan menerapkan metode Subtraction atau Subtractive Direct Method. Selain penerimaan negara lebih besar, pihak konsumen (shipper/eksportir) tidak merasa dirugikan karena adanya PPN atas selisih freight tersebut menjadi beban perusahaan freight forwarding.

- Disarankan Kementerian Keuangan qq Direktorat Jenderal Pajak me-revieu SE33/PJ/2013 dan PMK No.38/PMK.011/2013 yang diterbitkan, dan memperbaiki regulasi baru pemajakan atas freight yang telah dikeluarkan dengan menerapkan metode Subtraction atau Subtractive direct method didalam pengenaan PPN atas selisih freight dengan rumusan tarif PPN sebesar $10 \% \mathrm{x}$ selisih freight. Hal ini dilakukan dengan merubah SPT Masa PPN Formulir 1111 dengan cara merubah judul dibawah kolom III "PPN Terutang Atas Kegiatan Membangun Sendiri", menjadi "PPN atas Selisih Freight Pada Perusahaan Jasa Freight Forwarder dan "PPN Terutang Atas Kegiatan Membangun Sendiri”.

\section{UCAPAN TERIMA KASIH}

Penelitian ini didanai oleh Kemenristekdikti melalui "Hibah" Research Funding RISTEKDIKTI Tahun 2015, dan telah 
disetujui oleh RISTEKDIKTI sesuai surat No. 0299/E3/2016 tgl.27 Jan 2016.

\section{DAFTAR PUSTAKA}

Asri Harahap, Abdul. 2004. Paradigma Baru Perpajakan Indonesia.Jakarta : Integrita Dinamika Press.

Edward F Steven. 1975. Shipping Practice, $9^{\text {th }}$ edition : Pitman Publishing.

Hamonangan Simanjuntak, Timbul dan Imam Mukhlis. 2012. Dimensi Ekonomi Perpajakan Dalam Pembangunan Ekonomi.Depok :Raih Asa Sukses (Penebar Swadaya Group).

Ikatan Akuntan Indonesia. 2009.Standard Akuntansi Keuangan Per 1 Juli 2009. Jakarta: Salemba Empat.

Istopo. 1992. Unimoda dan Multimodal Transport, Angkutan Barang Terpadu Darat, Laut dan Udara. Jakarta.:Yayasan INFFA (Indonesia Freight Forwarder's Foundation).

Kosasih, Engkos dan Hananto Soewedo. 2012. Manajemen Perusahaan Pelayaran. Jakarta:PT. Radjagrafindo Persada.

Mansury, R. 1994 \& 1996.Panduan Konsep Utama Pajak Penghasilan Indonesia Jilid 1III.Jakarta :PT. Bina Rena Pariwara.

Martono, H.K. dan Eka Budi Tjahyono.2011. Transportasi Di Perairan Berdasarkan Undang-Undang Nomor 17 Tahun 2008. Jakarta : Rajawali Pers.

Nurmantu, Safri. 2005. Pengantar Perpajakan, edisi 3 .Jakarta : Granit.

Pohan, Chairil Anwar. 2017. Pembahasan Komprehensif Perpajakan Indonesia, Teori dan Kasus.Edisi 2.Jakarta : Mitra Wacana Media.

Rosdiana Haula dan Edi Slamet Irianto. 2012. Pengantar Pajak. Jakarta : Rajawali Press.

Rosdiana Haula dan Edi Slamet Irianto.2012.Pengantar Ilmu Pajak, Kebijakan dan Implementasinya di Indonesia. Jakarta : Rajawali Press.

Sugiyono. 2010. Memahami Penelitian Kualitatif. Bandung : Penerbit Afabeta.
Suyono, R.P. 2005. Shipping, Pengangkutan Intermodal Ekspor Impor Melalui Laut. Edisi 4.Jakarta:Penerbit PPM 